\title{
The Presence of the Prophet: General Introduction
}

\author{
Rachida Chih, David Jordan and Stefan Reichmuth
}

Attachment to the Prophet Muhammad is shared by all the various individuals, groups and communities that define themselves as Muslims, whether Sunnī, Shī'ì, Ibādì or others, whether attached to the letter or to the spirit of Islam, whether they are proponents of Islamic reform or secular Muslims. As a focus for personal emulation and normative precedence and as a source of hope for salvation and of cultural identity and socio - political empowerment, the Prophet of Islam continues his presence among the Muslim believers.

In his function as messenger of both divine mercy and wrath and as intercessor on behalf of his community in the present and in an eschatological future, the Prophet of Islam stands out as a necessary intermediary between God's transcendence and the human realm. The belief in Muhammad's intermediacy engendered a constant tension between the superhuman and human aspects of his person and message, which increased with the growing historical distance from him. The engagement with this tension ushered in the development of prophetology, and in diverse and sometimes contested forms of devotion to the Prophet. These have aimed to revivify his memory and his tradition, to directly or indirectly identify with him, and to look for encounters with him in blessings, dreams and visions.

The objective of this series is not another historical study of the life of the Prophet and of the origins of Islam. It rather approaches the significance of his image for his community with its diverse group affiliations and identities, in the course of history. What have been the foundations of the Muslims' attachment to the Prophet, and the modalities of his presence within their religious endeavours? What has been the role of his figure and memory in the construction of their identities and expectations?

In its quest of the "Historical Muhammad", academic research has largely pursued the aim of comprehending and reconstructing his historical personality as closely as possible, in the context of the beginnings of Islam, with all the tools of philological and historical criticism available for an assessment of 
the extant sources. ${ }^{1}$ Since the nineteenth century this has led a considerable number of scholars, including some Muslims, to write full biographies of the Prophet, with tendencies that clearly reflect their own world views and their academic formation in the context of their times. The classification applied by Arthur Jeffery to this literature already in $1926,{ }^{2}$ with its distinction between "pathological lives", "political and economic lives", "advanced criticism", "mythology", "eschatological lives", "apologetic lives", and "mysticism", would seem to have retained its usefulness even today.

The image of the Prophet as it was established in Muslim religious and historical tradition had, despite many critical objections, remained for a long time at the centre of historical reconstruction and dominated both positive and more critical accounts of the "Life of the Prophet". But in recent decades this image has been questioned and overshadowed by other research attempts. These locate the origins of Islam and the emergence and development of the Qurān in the context of the multireligious culture of the Middle East in late antiquity, and try to break fresh critical ground in the methodological approach toward these early developments. The resulting revision of the basic framework of both the textual genesis and collection of the Qurān, of the history of the early religious community from which Islam finally emerged, and of the life and role of the Prophet himself, puts great stress on the apocalyptic and eschatological dimensions of the early message. It assumes a redaction process of the Quraan which lasted until the end of the seventh century. ${ }^{3}$ In this new tableau of the emergence of Islam, the role of the Prophet appears more or less reduced to that of a shadowy military leader of an apocalyptic movement, which took on a specific religious shape only by its interactions with the different religious communities in the conquered regions of the Middle East.

1 For a highly useful collection of articles representing this field, Motzki, ed., The Biography of Muhammad; for a recent critical overview of the historiographical approaches to the Prophet, Shoemaker, "Les vies de Muhammad".

2 Jeffery, "The Quest for the historical Muhammad"; used again extensively by Shoemaker in his critical overview of the biographical literature on the Prophet, "Les vies de Muhammad" 212-26.

3 The monumental collection Le Coran des Historiens (3 vols. including a critical commentary of the Qurānic suras) edited recently by Muhammad Ali Amir-Moezzi and Guillaume Dye (2019) can be regarded as a collective product of this approach, which finds its recent programmatic expression in the general introduction written by Amir-Moezzi and Dye (21-37) and in Stephen J. Shoemaker's chapter "Les vies de Muhammad" (183-245). The beginnings of this approach can be identified with the works of John Wansbrough, Quranic Studies (1977), and The Sectarian Milieu (1978), with Patricia Crone and Michael Cook, Hagarism (1977), and with Patricia Crone's subsequent publications. 
Another approach to the Qurān has been followed by Angelika Neuwirth, who remains by and large attached to the chronological framework of its textual development as established in the Islamic scholarly tradition and further developed by Theodor Nöldeke in the nineteenth century. But she also explicitly attempts to disentangle the analysis of the Qurān from its connection with the received Prophetic vita. ${ }^{4}$ Looking at the Quraanic text as product of an interaction between the Prophet and his audience, she attempts to reconstruct the emergence of the Islamic community in the mirror of its chief document. The text itself conveys a prophetology which for her can be followed in its development. Its beginning can be read as transcendent addresses to a human individual, and it leads towards the affirmation of universal authority for a messenger who unites and supersedes all the previous channels of divine communication with mankind in his own person and in his script. ${ }^{5}$ Despite her strong opposition against "revisionist" assumptions and their chronology, one gains the impression that, in her works on the Qur'ann, too, the Prophet seems to lose his agency and to merge with both text and community ("Gemeinde"). She thus can be found in some vicinity to Fred Donner with his attempt at a reconstruction of an early "Believers' movement" which shaped the beginnings of Islam before and after the the Prophet' death. ${ }^{6}$

A comprehensive exploration of the biography of the Prophet of Islam and of the development of his image in the Arabic biographical and pious literature attached to his person was undertaken by Tilman Nagel $(2008,2010){ }^{7}$ His works stand in clear opposition to the historical devaluation of the Arabic sources for the life of the Prophet and for the beginnings of Islam in contemporary research, which is strongly criticised by him. ${ }^{8}$ According to Nagel a clear difference in character can be observed between the early sìra and maghāzi works and the reports about the Prophet enshrined in the hadith literature, which to him represents a later stage in the de - historicising of his image. He therefore proceeds to develop his own critical approach to the Arabic source materials and their relation to the Qurān. His image of the entanglement of religious and political factors in the life of the Prophet remains highly critical of both his personality and of that of his companions. In this respect Nagel's work can be seen as a continuation from older biographical accounts like those

4 See Neuwirth, Der Koran als Text der Spätantike, 107-122; 333-339; 407-413; Der Koran 2/1, 44ff.; it is telling that, in the first mentioned book, neither "Prophet" nor "Muhammad" figure in the index, cf. 841,845 .

5 See especially Neuwirth, Der Koran 2/1, 44ff.

6 Fred Donner, Muhammad and the Believers; see esp. Ch. 2, 44-89.

7 Nagel, Mohammed. Leben und Legende; Allahs Liebling; Mohammed. Zwanzig Kapitel.

8 Nagel, Mohammed. Leben und Legende, 35-43. 
of Sprenger, Buhl, and others. His critique also includes the Muslims' dogmatic and ahistorical attitude to their Prophet as it developed since the Umayyad period, which he sees as still at work in the current political and ideological uses of his image.

The Muslims' pious attachment to their Prophet, on the other hand, has certainly received some attention by Islamicists and anthropologists, especially since the beginnings of the twentieth century. The pioneering overviews of Max Horten (1916, 1917-18) and Tor Andrae (1918) have retained much of their value. $^{9}$ They already presented a panorama of early and medieval doctrines, traditions and beliefs concerning the exemplary figure of the Prophet with its strong supernatural touches in learned as well as popular culture within both Sunnī and Shīī Islam. This broad perspective was only further developed and augmented in the 1980s by Annemarie Schimmel $(1981,1985)$ with a close view on Sufi culture and poetry in different languages well into the modern period. ${ }^{10}$ Recent works with a more comprehensive approach like Brockopp (2010) and Fitzpatrick and Walker (2014) also take the Muslims' attachment to the Prophet into account. ${ }^{11}$ But it has to be stated that this perspective has remained marginal, in Islamology and even more so in the sociology of religions in general, and it was only rarely that scholars attempted to understand the nature of the bonds which have attached the Muslims to their Prophet until the present.

\section{Research on the Muslims' Attachment to the Prophet: Objectives and Approaches}

The increased attachment of the Muslims to the Prophet in recent times has certainly reinforced and deepened the existing fractures within Islam, and also the tensions and conflicts with non - Muslims, which have gained in intensity whenever the Prophet and his image are at stake. Under these circumstances, a major task for further research on the Prophet of Islam and on the continuous presence of his figure among the Muslims seems to lie in an exploration of the rich and varied historical and contemporary patterns of attachment to him, which have contributed to the formation of the Muslim individual and to the development of Islamic culture and politics. The three collective volumes

$9 \quad$ Horten, Die religiöse Gedankenwelt der gebildeten Muslime; Horten, Die religiöse Gedankenwelt des Volkes; Andrae, Die Person Muhammads.

10 Schimmel, And Muhammad is His Messenger; in German: Und Muhammad ist Sein Prophet.

11 Brokopp, ed., Cambridge Companion; Fitzpatrick and Walker, eds., Muhammad in History, Thought, and Culture. 
which are presented here, the product of a joint French-German research project, are dedicated to this task. ${ }^{2}$ They focus on the early modern as well as the modern period, which are taken here to cover the time spans between $145^{\circ}-$ $185^{\circ}$ and $185^{\circ}$ to the present, respectively. ${ }^{13}$ Taken together, both periods were a time of expansion but also decentring of Islam and of the Muslim world. With view to the longue durée of certain doctrines and attitudes connected with the Prophet, it was necessary sometimes to direct our attention also to earlier periods (especially in Volume I).

In addition to the study of the normative dimensions of Islam pursued by philological and juridical research, and of the political history of the Muslim world, the three volumes deal with the social and cultural dynamics of living Islam, with a view to the fact that religious norms and practices themselves, far from being fixed and defined once and for all, are at the heart of social action and in constant flux and adaptation. Masses and elites equally participate in this process of social interaction leading to the construction and redefinition of societal and religious norms. The Muslims' relations to the Prophet have yet to find their place in the history of mentalities and representations, and in the history of the Muslim world in general.

Rather than following the simplistic distinction between "popular Islam" and "scholarly Islam" which has long dominated research on Muslim societies, ${ }^{14}$ veneration and piety connected with the Prophet should be seen on a continuum which includes different social and cultural formations, at times producing a "Prophetic culture" of considerable social cohesion, shared between masses and elites. Equally, it would be fruitless to look for a homogenised figure of the Prophet Muhammad agreed upon by the whole of the Muslim community. His image was often determined by Sufi concepts and activities but also by religious milieus which were in opposition to Sufism.

Our task, then, is rather to account for the plurality of representations of the Prophet, which evolved in the course of Muslim history along with sometimes fierce debates and polemics. This is why we have chosen to gather specialists from different disciplines and methodologies around a threefold thematic focus on doctrinal and aesthetic representations, power relations, and devotional

\footnotetext{
12 "The Presence of the Prophet: Muhammad in the Mirror of his Community in Early Modern and Modern Islam", joint ANR-DFG project (2017-2020); see also its website https://prophet.hypotheses.org.

13 This periodisation follows the use of the Enzyklopädie der Neuzeit, Friedrich Jäger ed., published 2005-2012, extended since 2017, and its English edition, Encyclopedia of Early Modern History Online, Graeme Dumphy ed., then Andrew Colin Gow, since 2016.

14 For two influential representatives of this approach, see Geertz, Islam Observed; Gellner, Muslim Society.
} 
practice and experience. The interdisciplinary dialogue on these themes will hopefully contribute to a clarification of the Muslims' relation to their Prophet, and of the modalities of his presence among them in the past as well as in the contemporary world.

This presence of the Prophet, described by Tilman Nagel (2008) as "spiritual presence and universal ideological authority", includes eschatological beliefs about him which connect the beginnings of Islam (and for some also the origin of the whole created world) with the present time and the end of days. ${ }^{15}$ Eschatology is meant here to include not only future expectations of the end of times, but, in a sense already well established for Christianity, a certain fulfilment unfolding already in the present, sometimes called "realised" or "inaugurated eschatology". ${ }^{16}$ Regarded by some as the first created being in the world, as "Muhammadan Light" or "Muhammadan Reality", the Prophet is even imagined as encompassing and reflecting the whole cosmos. ${ }^{17}$ By implication, he can assume the role of mediator, intercessor and addressee for the inner life of the believer in pious practice and mysticism. These eschatological beliefs, too, confer an important position to the descendants of the Prophet (al-sāda al-ashräf) as reputed trustees of his sacred rank and heritage, and as "living links" to him (Morimoto). ${ }^{18}$ An auratic mediation between the historical distance of the Prophet and the presence of his words is evoked by the transmitted Prophetical sayings, which speak to the believer, provide edification and admonition, and demand obedience to his orders along with those of the Qurān..$^{19}$ They suggest blessing and even victory in this world for those who keep hold of the Prophetic sunna ("Vergegenwärtigung heilswichtiger Aussagen" $)^{20}$ and the moral and legal authority derived from his tradition has obvious political implications. The immediate encounter with the words and deeds of the Prophet can nourish the above-mentioned eschatological beliefs, but it can equally be experienced and maintained in strict distance from them.

15 "Spirituelle Gegenwärtigkeit wie auch ideologische Allzuständigkeit Mohammeds", Nagel, Allahs Liebling, 119 .

16 Cullmann, Heil als Geschichte; Kuhn, Enderwartung und gegenwärtiges Heil; Filoramo et al. "Eschatologie".

17 Rubin, "Pre-Existence and Light".

18 Morimoto, Sayyids and Sharifs.

19 For this notion of an "aura" created by the interplay of distance and closeness in the experience of a sacred or aesthetic object, which was brought up by Walter Benjamin, see his Das Kunstwerk im Zeitalter seiner technischen Reproduzierbarkeit [The Work of Art in the Age of its Technological Reproducibility]; Rochlitz, Disenchantment of Art; Spangenberg, "Aura"; Beil, Herberichs, Sandl, eds., Aura und Auratisierung. Schöller, Mohammed, 74, quoting Nagel. 
A point of departure for our project was the intensification of Prophetcentred patterns of piety in different cultural fields since the fourteenth century, which can be observed in virtually all regions of the Muslim world. This development increased with the emergence of the large Muslim empires of the Ottomans, Safavids and Mughals and of a number of other Muslim regional states. ${ }^{21}$ In a period of intense religious and socio-political struggles, eschatological expectations gained in fervour among Muslims, Christians and Jews on both sides of the Mediterranean, in larger parts of the Middle East and in Central and South Asia. ${ }^{22}$ Patterns of this piety had already emerged in the preceding centuries, and henceforth the Prophetic model increasingly moved among Muslims into the core of personal and collective efforts to strengthen the individual and to renew and expand Islamic culture and politics.

In general terms, piety can be understood as a personal and often affective commitment and effort to realise certain religious ideas, values and instructions in individual and collective life through a specific way of living. It includes both the living practice itself and its reflection and propagation. ${ }^{23}$ The three volumes aim to highlight the Muslim attachment to the Prophet and the attempts at his representation in quite diverse individual and collective ways of living, based on both affective and intellectual bonds, within and beyond the Muslim world. This broad concept of a "Prophetic piety" includes both religious practice and doctrinal and institutional settings. It also extends to literary genres like prayer, praise poetry, juridical and Sufi treatises, to literature and the arts, and also to the political sphere. ${ }^{24}$ For all its manifold forms and expressions, attachment to the Prophet can be found mainly in the three key modes of imitation, identification, and interaction, which may serve as a taxonomy for the categorisation of Prophetic piety.

Throughout history, Muslims have emphasised the salience of imitating the Prophet Muhammad as an "excellent model" (uswa hasana, Qur'ān 23:21) for personal behaviour as well as for public action, by accepting his message and following his Sunna. The focus later shifted to his acceptance as the best of human beings, to the duty to love him and to acquire as many traits as possible of his noble character. The above-mentioned concept of the "Muhammadan

21 For an overview see Reichmuth, "Aspects of Prophetic Piety"; for the Safavid and Mughal empires, Moin, Millennial Sovereign.

22 See Subrahmanyam, "Du Tage au Gange au XVIe siècle".

23 Hamm, "Frömmigkeit als Gegenstand theologiegeschichtlicher Forschung", 466. For a general discussion about the ambiguity of the term piety and the difficulty of defining it in a Christian context, see Fassbinder, "Frömmigkeit". For an influential study on modern Muslim female piety, see Saba Mahmoud, Politics of Piety.

Reichmuth, "Aspects of Prophetic Piety", $129 f$. 
Light" as the first creation (found already with al-Tustarī, d. 283/896) reflected a cosmological turn in the view of the Prophet which developed among Sunnīs through close exchange with Shīi t thought. The shift towards a more personal orientation vis-à-vis the Prophet, which found its most articulate expression in the twelfth century with al-Qāḍi ' Iyād (d. 544/1149) and his Kitāb al-shifä̀, was to deepen over the following centuries. It can be observed that even those critics of Sufism who fiercely struggled against Muhammad's cosmic and superhuman idealisation came to share an increasingly "Prophetocentric" worldview with their adversaries. Their strong emphasis on the human character of the Prophet, whose biography and tradition reach a paradigmatic role for nearly all aspects of daily human life, can today be observed among Sufis, Islamists, and in the discourse of the global da'wa alike. With this "Sunnatisation of lifeworlds", 25 imitation of the Prophet has become important in the construction of modern Muslim individual and collective identities worldwide.

Building on this imitation, the Prophet and also his family (ahl al-bayt) became central figures of identification and pride and a source of authority among Muslim individuals and communities. Whether religious scholars and jurists, Sunnī or Shīì religious leaders, Sufis, reformists, and even rulers, they all directly or indirectly identified as heirs of the Prophet and in this way derive legitimacy as his rightful successors as well as transmitters and trustees of his heritage. This often involved the claim to a calling as a "renewer" (mujaddid) of the Sunna and of the Muslim community, and also of an authentic representation of the Prophet himself. The identification with the person of the Prophet also remains strong in the secular political movements of the twentieth century, and even in Muslim accounts of his life which show their - sometimes rather critical - engagement with Orientalist scholarship. ${ }^{26}$

Claimants of Prophetic authority often undergirded their cause through the ownership and use of Prophetic relics and vestiges (hair, teeth, footprints, mantles, swords, banners), ignoring the strong reformist critique against such uses. The bodily visualisation of these items functions as a powerful tool in order to create an aura of protection and blessing for the owner and the audience through their immediate and physical presence. A direct identification with the Prophet, and "living links" to him are also offered by his descendants (al-sāda al-ashräf), who, as mentioned above, have often enjoyed a special social and religious status as bearers of his outward and inward perfection,

25 See for this Malik in Malik and Hinnells, eds., Sufism in the West, 3.

26 Like those of Muhammad Haikal (d. 1956), Hayāt Muhammad, and Hisham Djait (b. 1935), al-Wahy wa-l-Qur'ān wa-l-nubuwwa; Tārïkhiyyat al-da'wa. On Djait and his views on the Prophet and the Qurānn see Sinai, "Hisham Djait". 
moral purity, and blessing. From the fifteenth to the nineteenth century, the number of claimants to Prophetic descendance and their impact on social and political life increased tremendously across various societal spheres in the Islamic world, henceforward strongly shaping Muslim society and culture as they could enhance Islamic legitimacy through a sanctified genealogical link to the Prophet.

Many Muslim individuals and communities, finally, show a desire for interaction and communication with the Prophet in prayers, dreams and visions and also in recitations of his sayings or of poetry in his praise, which seems to have increased during the early modern period. Dreams and visions continue to have a special role in Islam as the only part left of prophecy (mubashshirāt), and as a crucial element of personal religious experiences evoking the Prophet's presence (according to widespread theological conviction the Prophet is believed to remain alive in his grave $)^{27}$ and even allowing for union with him. Literary reports about such encounters abound throughout history, and they are still searched for, transmitted and discussed today in pious circles of both Sufi and Salafi orientation. Believers secure personal access to relics, vestiges, and historic places connected with his life, surround themselves with calligraphic representations of his names and his reported personal appearance (hilya), and constantly say the benediction upon him (al-șalāt 'alā an-nabì) whenever his name is mentioned. Hope and prayer for his intercession (shafä $a)$ at Judgement Day and his approachability for calls for help (tawassul, istighātha) in everyday life became dominant, though often contested, theological issues. Poems in praise of the Prophet (madị or $n a^{c} t$ ) were since the later middle ages conceived as precious gifts to him, connected with the hope to be rewarded with his intercession for author, performers and audience alike.

The artful recitation of poetry in praise of the Prophet, performed especially on his birthday (mawlid), thus became a powerful means of bringing about an encounter with him. The auratic character (on which see above) of the ensemble of discursive and sonic performances can evoke profound sensations, like the feeling of being moved to his tomb in Medina. ${ }^{28}$ The aforementioned transmission and recitation of the Prophet's sayings appears to convey a similar auratic impression to Sufis, non-Sufis and anti-Sufis alike; an impression that does not seem to be diminished by its "technological reproducibility", quite in contrast to what Walter Benjamin would describe for the fate of art in modern society. ${ }^{29}$

27 Meier, "Auferstehung Muhammads".

28 Eisenlohr, Sounding Islam.

29 Benjamin, Kunstwerk; Rochlitz, Disenchantment. 
The first volume of the series focuses on the figure of the Prophet as presented and discussed in Islamic knowledge and doctrine, which was constructed and progressively established in the formative age of Islam, and further re-read and re-appropriated in early modern and modern times. As mentioned above, the reconstruction of these formative doctrinal elements and their impact required a good number of thematic recourses to earlier Islamic times. Doctrinal developments are viewed in this volume in interaction with the different modes of aesthetic representation of the Prophet in literature and the arts. Here, as in the field of doctrine, the focus is on the tension between the divine and human realms, connected in the person and message of the Prophet, and their mediation in different forms of textual and aesthetic representation. The complementary focus joining doctrinal, literary and artistic perspectives has only rarely been attempted until now. It promises to provide fresh insights into the interplay of knowledge and culture in Muslim communities, both in their historical and contemporary dimensions.

The theme of the second volume is the role played by the heritage and model of the Prophet Muhammad as a successful and divinely guided war leader and statesman, which inspired many Muslim communities of different times and regions in their manifold and often opposing political projects. This included the foundation and running of imamates, sultanates and rural and tribal federations, right down to the modern nation states and to secular political movements. Special attention is given to the descendants of the Prophet and their leading roles in various societal spheres, and their emergence as political leaders and founders of states in different parts of the Muslim world, especially in the early modern period.

The volume equally highlights another important dimension of the Prophetic model. That is his significance for the self-empowerment of Muslim individuals and communities in their resistance against foreign powers, and even against their own governments. Reference to his model and life served to justify an opposition that often included the elaboration of radical political ideologies and of militant action. It has also frequently come up in communal struggles, and in the attempted founding of Islamic states by militant Islamic movements in recent times. The image of the Prophet thus appears as a mirror of the conflictual forces within contemporary Muslim societies, and of their strained relationships with the non-Muslim world.

The third volume, by interlacing historical and anthropological approaches, explores the different practices of piety and devotion connected with the Prophet, whether as individual activities or as group expression. Its focus is on festivals and celebrations, especially those of the Birthday of the Prophet 
(mawlid al-nabī) in different countries, religious and social milieus. The volume also discusses the debates around these celebrations and other forms of veneration of the Prophet and his descendants, which have gained in vigour over the last century and have created a novel Muslim debate over the ways of thinking of the Prophet and of connecting with him, in contexts which are strikingly different from those of the medieval polemics.

The volume also highlights the impact of the Prophetic model on individual and collective identity formation among Muslims. The focus will be particularly on Western Europe, and on the role of the Prophet for Muslim religiosity in European secular societies. Other forms of Muslim attachment to the Prophet will also be discussed. They include the devotion to his reputed bodily traces and relics, which survives until today in many parts of the Muslim world, the articulation of his presence in reported dreams and visions, and the religious and emotional framework connected with benedictions for him and with poetry and chanting in his praise.

\section{Bibliography}

Andrae, T. Die person Muhammads in leben und glauben seiner gemeinde, Stockholm, P. A. Norstedt, 1918.

Beil, U. J., Herberichs, C., and Sandl, M. eds., Aura und Auratisierung. Mediologische Perspektiven im Anschluss an Walter Benjamin, Zürich, Chronos Verlag, 2014.

Benjamin, W. Das Kunstwerk im Zeitalter seiner technischen Reproduzierbarkeit. Kommentar von Detlev Schöttker, Frankfurt, Suhrkamp, 2015.

Benjamin, W. "The Work of Art in the Age of Its Technological Reproducibility", in M. W. Jennings, B. Doherty, and T. Y. Levin, eds., The Work of Art in the Age of Its Technological Reproducibility, and Other Writings on Media, Cambridge, MA, Belknap Press, 2008.

Brockopp, J. E., ed. The Cambridge Companion to Muhammad, Cambridge University Press, 2010. https://doi.org/10.1017/CCOL9780521886o79.

Cook, M., and Crone, P. Hagarism. The Making of the Islamic World, Cambridge University Press, 1977.

Cullmann, O. Heil als Geschichte: heilsgeschichtliche Existenz im Neuen Testament, Tübingen, Mohr, 1965 .

Donner, Fr. Muhammad and the Believers: At the Origins of Islam, Cambridge, M.A., The Belknap Press of Harvard University Press, 2010.

Eisenlohr, P. Sounding Islam: Voice, Media, and Sonic Atmospheres in an Indian Ocean World, Oakland, California, University of California Press, 2018.

Dunphy, G., Gow, A. C. eds., Encyclopedia of Early Modern History Online, Leiden, Brill, since 2016. https://referenceworks.brillonline.com/browse/encyclopedia-of -early-modern-history-online. 
Fassbinder, S. "Frömmigkeit. Entwicklung und Problemfelder eines Begriffs", Saeculum 47, 1 (1996), 6-34. https://doi.org/10.7788/saeculum.1996.47.1.6.

Filoramo, G. H., et al. "Eschatologie", in Religion in Geschichte und Gegenwart, Brill Online, 2015. https://referenceworks.brillonline.com/entries/religion-in-geschichte -und-gegenwart/eschatologie-COM_04625?s.num=96\&s.start=80.

Fitzpatrick, C., and Walker, A. H., eds., Muhammad in History, Thought, and Culture: An Encyclopedia of the Prophet of God, Vol. 2., Santa Barbara, CA, ABC-CLIO, 2014.

Geertz, C. Islam Observed, New Haven, Yale University Press, 1968.

Gellner, E. Muslim Society, Cambridge University Press, 1981.

Hamm, B. "Frömmigkeit als Gegenstand theologiegeschichtlicher Forschung: Methodisch-historische Überlegungen am Beispiel von Spätmittelalter und Reformation", Zeitschrift für Theologie und Kirche 74, 4 (1977), 464-97.

Haykal, M. Hayāt Muḥammad, Cairo, Maṭba'at Miṣr, 1935.

Horten, M. Die religiöse Gedankenwelt der gebildeten Muslime im heutigen Islam, Halle, Niemeyer, 1916.

Horten, M. Die religiöse Gedankenwelt des Volkes im heutigen Islam, Halle, Niemeyer, 1917.

Jäger, F., ed. Enzyklopädie der Neuzeit, Vols. 1-16, Stuttgart, Verlag J. B. Metzler, 20052012. Online: https://referenceworks.brillonline.com/browse/enzyklopaedie-der -neuzeit.

Jeffery, A. "The Quest for the Historical Muhammad", The Moslem World 16 (1926), $327-48$.

Ju'ayyiṭ (Djait), H. Al-Waḥy wa-l-Qur'ān wa-l-nubuwwa, Beirut, Dār al-țalīa, 1999.

Ju'ayyiṭ (Djait), H. Tārīkhiyyat al-da'wā al-Muhammadiyya fì Makka, Beirut, Dār al-țalī‘a, 2007.

Kuhn, H-W. Enderwartung und gegenwärtiges Heil: Untersuchungen zu den Gemeindeliedern von Qumran mit einem Anhang über Eschatologie und Gegenwart in der Verkündigung Jesu, Studien zur Umwelt des Neuen Testaments 4. Göttingen, Vandenhoeck and Ruprecht, 1966.

Mahmoud, S. Politics of Piety. The Islamic Revival and the Feminist Subject, Princeton University Press, 2011.

Malik, J. and Hinnells, J., eds. Sufism in the West, Abingdon, Routledge, 2006.

Malik, J. "Fiqh al-Dacwa: The Emerging Standardization of Islamic Proselytism", Die Welt des Islams 58 (2018), 206-43.

Meier, F. "Eine Auferstehung Muhammads bei Suyūṭ̂", Der Islam 62, 1 (1985), 20-58.

Moin, A. A. The Millennial Sovereign. Sacred Kingship and Sainthood in Islam, New York, Columbia University Press, 2012.

Morimoto, K., ed. Sayyids and Sharifs in Muslim Societies: The Living Links to the Prophet, Abingdon, Routledge, 2011. 
Motzki, H. ed. The Biography of Muhammad: The Issue of the Sources, Leiden, Brill, 2000.

Nagel, T. Mohammed. Leben und Legende, München, Oldenbourg, 2008.

Nagel, T. Allahs Liebling: Ursprung und Erscheinungsformen des Mohammedglaubens, München, Oldenbourg, 2008.

Nagel, T. Mohammed. Zwanzig Kapitel über den Propheten der Muslime, München, Oldenbourg, 2010.

Neuwirth, A. Der Koran als Text der Spätantike. Ein europäischer Zugang, Berlin, Verlag der Weltreligionen, Insel Verlag, 2010.

Neuwirth, A. Der Koran. Handkommentar mit Übersetzung. Band 1. Poetische Prophetie. Frühmekkanische Suren, Berlin, Verlag der Weltreligionen, Insel Verlag, 2011.

Neuwirth, A. Der Koran. Band 2/1. Frühmittelmekkanische Suren. Das neue Gottesvolk: „Biblisierung“ des altarabischen Weltbildes. Handkommentar, Berlin, Verlag der Weltreligionen, Insel Verlag, 2017.

Reichmuth, S. "Aspects of Prophetic Piety in the Early Modern Period", Archives de Sciences Sociales des Religions, 178 (2017), 129-150.

Rochlitz, R. The Disenchantment of Art: The Philosophy of Walter Benjamin, trans. J. Todd, New York, Guilford, 1996.

Rubin, U. "Pre-Existence and Light: Aspects of the Concept of Nūr Muhammad" Israel Oriental Studies 5 (1975), 62-119.

Schimmel, A. And Muhammad Is His Messenger: The Veneration of the Prophet in Islamic Piety. Studies in Religion, Chapel Hill, NC, University of North Carolina Press, 1985. German: Und Muhammad ist Sein Prophet: Die Verehrung des Propheten in der islamischen Frömmigkeit, Köln, Diederichs, 1981.

Schöller, M. Mohammed. Leben Werk Wirkung, Suhrkamp-Basis Biographie 34, Frankfurt am Main, Suhrkamp, 2008.

Shoemaker, S. J. "Les vies de Muhammad", in M. A. Amir-Moezzi and G. Dye, eds., Le Coran des historiens, Paris, Cerf, 2019, I, 183-245.

Sinai, N. "Hisham Djait über die 'Geschichtlichkeit der Verkündigung Muhammads”, Der Islam 86 (2011), 30-43.

Spangenberg, P. M. “Aura”, Ästhetische Grundbegriffe. Vol. 1. Stuttgart, J. B. Metzler, 2000, 400-416.

Subrahmanyam, S. "Du Tage au Gange au XVIe siècle: une conjoncture millénariste à l'échelle eurasiatique", Annales 56, 1 (2001), 51-84.

Wansbrough, J. Qurānic Studies. Sources and Methods of Scriptural Interpretation, Oxford University Press, 1977.

Wansbrough, J. The Sectarian Milieu. Content and Composition of Islamic Salvation History, Oxford University Press, 1978.

Williams, R. R. Muhammad and the Supernatural: Medieval Arab Views, Routledge Studies in Classical Islam, 3, London, Routledge, 2013. 